\title{
Techno-Economic Study of Copper Removal from Acid Mine Drainage by Ion-Exchange Technique
}

\author{
R.W. Gaikwad ${ }^{a, *}$, R.S. Sapkal ${ }^{b}$ and V.S. Sapkal ${ }^{b}$ \\ ${ }^{a}$ Department of Chemical Engineering, Pravara Rural Engineering College, Loni, Dist Ahmednagar (MS)-413736, India \\ ${ }^{b}$ Department of Chemical Technology, SGB Amravati University, Amravati, India
}

\begin{abstract}
Economic feasibility has been studied for removal of copper from acid mine drainage wastewater by ion exchange. Ion exchange method has been used for removal of copper from industrial wastewaters. Experiments were conducted using packed bed column. The present study were carried out for solutions with concentrations of $100 \mathrm{mg} / \mathrm{lit}$ to $200 \mathrm{mg} / \mathrm{lit}$ and $\mathrm{pH}$ values of 3 to 6 , using Indion 730, strong acid cation exchange resin. Under the present operating conditions considered, the strong acid type resin was found to bring down initial copper content by almost 46-56\% and at $\mathrm{pH} 5,60 \%$ of copper removal for $200 \mathrm{mg} / \mathrm{lit}$ of initial concentration was found. The techno economic feasibility was then studied and the rate of return found to be $21 \%$ which is economically viable.
\end{abstract}

Keywords: copper, AMD, ion-exchange, economics

\section{Introduction}

Acid mine drainage (AMD) continues to be an important water pollution problem in mining industry around the world. When sulphide/pyretic minerals are exposed to the atmosphere, in presence of water oxidation of sulphide produces sulphuric acid and releases heavy metals and other pollutants to the drainage. When these sulphide minerals are processed in mineral processing units releases acidic effluents and also contains some other toxic substances, which are used in mineral processing. Further, the mill tailings amount to about $90 \%$ of ore is dumped in tailing impoundments and seepage from these impoundments can be source of AMD. AMD is often characterized by low $\mathrm{pH}$ water with elevated concentrations of iron, sulphates and heavy metals of varying composition dependent upon the originating mineral deposit types. The metal load is of greater concern than the acidity in the terms of environmental damage [1-5]. An hazardous feature of AMD is that its sources may remain active for decades or even centuries after mine closure [6]. Both operating and abandoned polymetallic sulphide mining sites are often active sources of AMD.

Several techniques such as chemical precipitation, oxidation, reduction, coagulation, solvent extraction, and adsorption have been commonly employed for the removal of metal ions. A review of treatments have been presented by Gaikwad and Gupta $(7,8)$.Among these, ion exchange has been thought to be efficient and economically feasible as a wastewater

${ }^{*}$ Corresponding author. Tel.: +91-2422-273204

Fax: +91-2422-273537; E-mail: rwgaikwad@yahoo.com

(C) 2013 International Association for Sharing Knowledge and Sustainability

DOI: 10.5383 /ijtee.06.02.006 treatment operation. Several resins can be used to remove metal ions, including activated carbons, alumina, silica, bentonite and peat. The Yi group $[9,10,11]$ has also studied the removal of inorganic metal ions namely cadmium, cobalt, zinc, silver, copper, mercury, chromium and lead from aqueous solution by using different adsorbents. Ion exchange resins with improved sorption capacity as well as adsorbents may have advantages over such non-specific adsorbents [12]. In this regard, ion exchange resins hold great potential for the removal of heavy metals from water and industrial wastewater [13, 14]. In the present study, Indion 730 cation exchange resin was used for the removal of copper from aqueous solution. Copper compounds are present in acid mine drainage wastewater.

\section{Materials and Methods}

The cation exchange resins Indion 730 (Ion Exchange India Limited, India) used in this study are used for the removal of heavy metals from water and wastewater. Their physical properties and specifications are presented in Table 1. All the chemicals used were of analytical grade.

A stock solution of $\mathrm{Cu}^{+}(1000 \mathrm{mg} / \mathrm{lit})$ was prepared by dissolving $3.929 \mathrm{~g}$ of $\mathrm{CuSO}_{4} \cdot 5 \mathrm{H}_{2} \mathrm{O}$ (Sd. Fine Chemicals Mumbai) in distilled water. The stock solution was diluted as required to obtain standard solutions containing 50 to $250 \mathrm{mg}$ $\mathrm{L}^{-1}$ of $\mathrm{Cu}$ (II). The schematic diagram of experimental set up has been shown in the fig.1. It consists of tank T1 which contains the metal stock solution. This tank is connected to a pump which pumps the solution through rotameter in to the cation exchange column. 
Table 1: Characteristics properties of the ion exchange resins used

\begin{tabular}{ll}
\hline Indion 730 (strong acid cation exchange resin) & \\
\hline Physical form & Greyish coloured spherical beads \\
Ionic form as supplied & Hydrogen e \\
Moisture holding capacity & $54-57 \%(\mathrm{H}+$ form $)$ \\
Particle size & $0.3-1.2 \mathrm{~mm}$ \\
Uniformity coefficient & 1.7 max. \\
Total exchange capacity & $1.7 \mathrm{meq} \mathrm{mL}^{-1}$ \\
pH range & $0-14$ \\
\hline
\end{tabular}

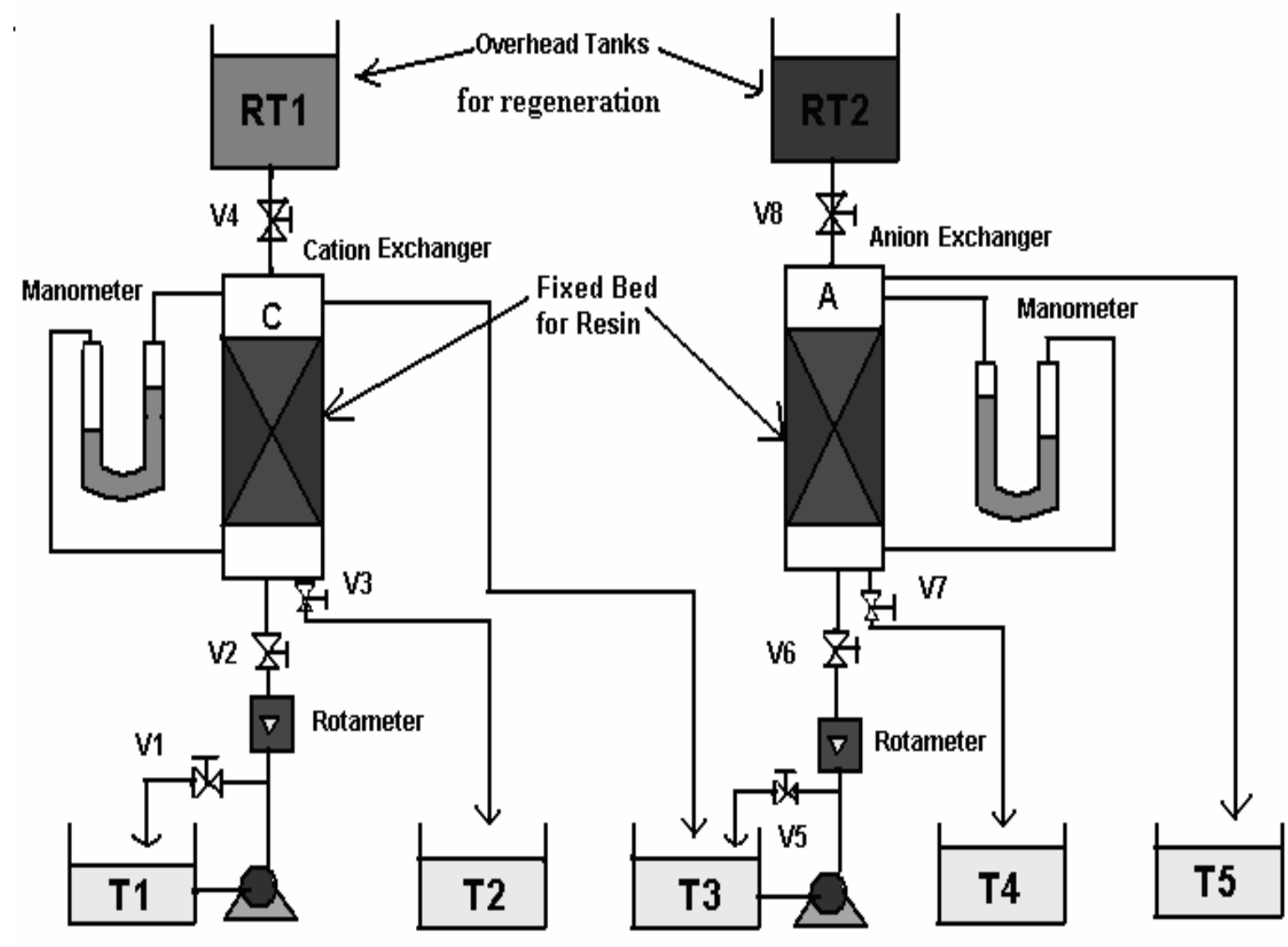

Fig. 1 Experimental Set Up

The outlet at the top of the column helps to withdraw the treated solution. A manometer is connected across the column for the pressure measurement. RT1 is the tank containing regenerating solution placed right on the top of the column. The solution after regeneration is collected in the tank T2. For anion exchange column, solution is pumped from the tank T3 in to it. The treated sample is collected in tank T5. Rotameter for flow measurement and manometer for pressure measurement is provided for the column. RT2 is the tank containing regenerating solution placed right on the top of the column. The solution after regeneration is collected in the tank T4. Both exchange columns are of $50 \mathrm{~mm}$ diameter and 1000 $\mathrm{mm}$ height. The material of construction is borosil glass.

\subsection{Experimental Procedure:}

The water is pumped in to the column prior to resin is being added. The resin was then added as wet slurry. This was to prevent air bubbles from being trapped between the particles, hence poor contacting in the column during each cycle.

\subsubsection{Service Cycle of cation exchanger:}

The solution containing metal is filled in the tank T1 and pumped through rotameter in to cation exchanger. Rotameter measures the flow rate and manometer the pressure drop. The treated sample from column is taken out from the top of the column and collected in the tank T3 and analyzed for the 
metal content from time to time. The process continues until the metal content reaches the discharge limit. Once this stage has been reached, the supply of metal solution is stopped. Now the regeneration process is carried out before the exchanger column is backwashed by water.

\subsubsection{Regeneration of cation exchanger:}

For regeneration, the regenerative solution HCL, from the tank RT1 is allowed to flow through the exchange column drop by drop for $3 \mathrm{Hrs}$. HCL regenerant removes the cations adsorbed during the service cycle and converts the resin to hydrogen form for the next service cycle. This solution is collected in the bottom tank T2. The recovery of the metal is achieved in this step.

\subsubsection{Back washing of cation exchanger:}

For backwashing, the tank $\mathrm{T} 1$ is filled with water and valves V3 and V4 are closed and valves V1 and V2 are opened. The water from tank $\mathrm{T} 1$ is pumped into the column with force for 10 minutes and taken out from the top of the column.

\subsubsection{Service Cycle of anion exchanger:}

The solution from tank T3 is pumped in to the anion exchanger. During this, the valves V5 and V6 are opened and valve V7 and V8 are closed. The flow rate is measured by rotameter and pressure drop by manometer. The treated solution is taken out from the top of this column and collected in the tank T5 and analyzed for acidity of the sample by titration method. The solution collected from the H-type resin column is fed the $\mathrm{OH}$ type anion resin column for conversion where acidity of wastewater is neutralized.

\subsubsection{Regeneration of anion exchanger:}

For regeneration, the regenerative solution $\mathrm{NaOH}$, from the tank RT2 is allowed to flow through the exchange column drop by drop for 3 Hrs. Regenerant removes the anions adsorbed during the service cycle. This solution is collected in the bottom tank T4.

\subsubsection{Back washing of cation exchanger:}

The column is backwashed with water after the regeneration cycle is completed. The backwash step removes the particulate matter filtered out by the exchanger during service and also regenerate the bed eliminating any channels which may have formed.

\subsection{Ion Exchange process for $\mathrm{Cu}$ recovery:}

In this section, the basic principle of the two-stage ion exchange process is illustrated. The process is in essence a four-step operation. In the first step, $\mathrm{Cu}$ is adsorbed onto the solid (the $\mathrm{H}$-type resin) phase by exchange with $\mathrm{H}$ which is combined with $\mathrm{H}+$ in the aqueous solution to form $\mathbf{H}_{2} \mathbf{S O}_{4}$. In the second step, the exhausted cations resins are regenerated using $5 \mathrm{wt} \% \mathrm{HCL}$ and the adsorbed $\mathrm{Cu}$ in the solid phase is replaced by $\mathrm{H}$ and is detached and combines with $\mathrm{Cl}^{-}$in the aqueous solution to form $\mathrm{CuCl}_{2}$. These first two steps of ion exchange can be represented by

$\mathrm{H}_{2} \mathrm{R}+\mathrm{CuSO}_{4} .5 \mathrm{H}_{2} \mathrm{O} \longrightarrow \mathrm{RCu}+\mathrm{H}_{2} \mathrm{SO}_{4}+5 \mathrm{H}_{2} \mathrm{O}$

Regeneration:

$\mathrm{RCu}+2 \mathrm{HCl} \longrightarrow \mathrm{RH}_{2}+\mathrm{CuCl}_{2}$ where $\mathrm{RH}$ represents the H-type ion exchange resin. It is noted that between the adsorption and desorption steps, $\mathbf{C u S O}_{4}$ in the original waste acid solution is significantly converted to form $\mathrm{CuCl}_{2}$ after desorption, as shown in the second reaction. In the third step, the $\mathrm{SO}_{4}$ ion in the aqueous solution is adsorbed by ion exchange with $\mathrm{OH}^{-}$on the solid phase and the sulfuric acid is neutralized according to following reaction.

$\mathrm{R}^{\prime}(\mathrm{OH})_{2}+\mathrm{H}_{2} \mathrm{SO}_{4} \rightarrow \mathrm{R}^{\prime} \mathrm{SO}_{4}+2 \mathrm{H}_{2} \mathrm{O}$

where $\mathrm{R}^{\prime} \mathrm{OH}$ is the OH-type ion exchange resin. In the final step, the exhausted ion exchange resin $\left(\mathrm{R}-\mathbf{S O}_{4}\right)$ is regenerated by 10 wt $\% \mathrm{NAOH}$ solution in which $\mathrm{OH}^{-}$is exchanged with $\mathrm{SO}_{4}$ on the solid phase to form $\mathbf{N a}_{2} \mathbf{S O} \mathbf{O}_{4}$. This last step is represented by

Regeneration: R'SO4 + $2 \mathrm{NaOH} \rightarrow \mathrm{R}^{\prime}(\mathrm{OH})_{2}+\mathrm{Na}_{2} \mathrm{SO}_{4}$

These four steps complete the process of copper removal, recovery and acid neutralization.

\section{Results and Discussion}

\subsection{Effect Of pH:}

The effect of $\mathrm{pH}$ on copper removal is shown in Fig.2 . It is well known that solution $\mathrm{pH}$ is an important factor controlling the surface charge of the adsorbent and the degree of ionization of the adsorbate in aqueous solution [15]. The effect of $\mathrm{pH}$ on the removal of copper (II) ions was tested at different $\mathrm{pH}$ values (3-6) using Indion 730 cation-exchange resin at constant copper (II) ions concentration $(200 \mathrm{mg} / \mathrm{L})$. The results indicated that the maximum uptake of copper (II) ions occurred at initial $\mathrm{pH}$ of 5 . The adsorption capacity of the resin increased with increase in $\mathrm{pH}$ up to 5 and then decreased with increase in $\mathrm{pH}$ of the aqueous solution. The copper removal by the resin is higher at $\mathrm{pH} 5$. Therefore, all the copper removal experiments were carried out at $\mathrm{pH} 5$.

\subsection{Effect of initial concentration:}

Column experiments were carried out by varying the $\mathrm{Cu}$ (II) concentration between 100 and $200 \mathrm{mg} / \mathrm{L}$ to determine the effect of adsorbate concentration on the performance of the $\mathrm{Cu}$ (II) removal. During these experiments, other parameters like $\mathrm{pH}(5)$, bed height $(60 \mathrm{~cm})$ and flow rate $(5 \mathrm{~L} / \mathrm{h})$ were kept constant. The sorption curve obtained for adsorbate concentrations of 100, 150, $200 \mathrm{mg} / \mathrm{L}$ are given in Fig. 3. The breakthrough time decreased with increase in inlet $\mathrm{Cu}$ (II) concentration as the binding sites became more quickly saturated. The equilibrium $\mathrm{Cu}$ (II) uptake and the total $\mathrm{Cu}$ (II) adsorbed were found to increase with increase in inlet $\mathrm{Cu}$ (II) concentration. The percentage of $\mathrm{Cu}$ (II) removal decreased with increase in adsorbate concentration.

With increase in initial $\mathrm{Cu}$ (II) concentration from 100 to $200 \mathrm{mg} / \mathrm{L}$, the total $\mathrm{Cu}$ (II) adsorbed, were found to increase from 1103.3 to $1637.92 \mathrm{mg}$ (Fig. 4). But the percentage $\mathrm{Cu}$ (II) removal decreased from 66 to 49.15 when the inlet $\mathrm{Cu}$ (II) concentration increased from 100 to $200 \mathrm{mg} / \mathrm{L}$.

The increase in uptake capacity of the adsorbent may be due to high inlet $\mathrm{Cu}$ (II) concentration providing higher driving force for the transfer process to overcome the mass transfer resistance. As seen in Fig. 3, for low inlet concentrations of $\mathrm{Cu}$ (II), the curve occurs late and surface of the adsorbent is saturated with $\mathrm{Cu}$ (II) after a long time whereas for higher $\mathrm{Cu}$ (II) concentration, the curve occurred in a short period of time. 


\subsection{Cost Benefit Analysis:}

The cost benefit analysis of $\mathrm{Cu}$ (II) recovery system has been done and given in Table 2. . It was based on prevailing Indian market rates of the year 2008-2009. The overall cost of ion exchange equipment involves two main factors namely fixed capital and running capital.

\subsection{Techno-Economic Feasibility Report:}

Techno-economic feasibility can be studied by considering profit return of standard percentage return obtained by total capital investment of `48720.00

1) Flow rate maintained $=15 \mathrm{lit} / \mathrm{hr}$

Effluent treated per year $=15 * 16 * 300=72000$ liters

(1 year equal to 300 operating days and 1 day equal to 16 operating hours)

2) Copper concentration in effluent per year $=200 * 72000$

$$
=14.4^{*} 10^{6} \mathrm{mg}
$$

3) Assuming $75 \%$ recovery of copper in the form of cupric chloride $=14400 * 0.75=10800 \mathrm{gm} .=10.80 \mathrm{Kg}$.
4) From the Stoichiometry:

127 gms of copper $=197 \mathrm{gms}$ of cupric chloride, 10800 gms of copper $=(197 * 10800) / 127$ gms of cupric chloride $=16752.75 \mathrm{gms}=16.75 \mathrm{Kg}$ of cupric chloride

5) Market price of cupric Chloride (100\% pure) $=1400$ per Kg.Neglecting packing and other miscellaneous charges Total price of cupric chloride recovered $=1400 * 16.75$ $=23450.00$

6) Net profit earned excluding all charges $=23450-13720.00$ $=9730.00$

7) Standard percentage $=($ net profit/total investment $) * 100$

$$
=(9730 / 45720.00) * 100=21.28 \%
$$

From these calculations, the process is economically feasible.

\begin{tabular}{|c|c|c|}
\hline SN & Particulars & Amount in \\
\hline \multirow[t]{4}{*}{1} & Fixed capital: & \\
\hline & A) Cost of Ion exchange column= & $30,000.00$ \\
\hline & Cost of installation $=10 \%$ of fixed capital investment & 5000.00 \\
\hline & Total fixed capital investment $=\mathrm{A}+\mathrm{B}$ & $35,000.00$ \\
\hline \multirow[t]{10}{*}{2} & B) Running Capital: & \\
\hline & a) Labor charges ( $10 \%$ of fixed capital) & 3000.00 \\
\hline & b) Electricity charges: Pump drive $=0.030 \mathrm{KW}$ & \\
\hline & Operating days $=300$ days $\&$ Operating hrs $/$ day $=16 \mathrm{hrs}$ & \\
\hline & Electricity consumption per pump per year $=0.03 * 16 * 300=144 \mathrm{KWH}$ & \\
\hline & Electricity charges per unit & 5.00 \\
\hline & Electricity charges per year & 720.00 \\
\hline & c) Operation and maintenance cost ( $10 \%$ of fixed capital) & 3000.00 \\
\hline & d) Procurement cost of raw material & 4000.00 \\
\hline & Running cost of equipment $=a+b+c+d$ & 10720.00 \\
\hline \multirow[t]{5}{*}{3} & Overall cost of ion exchange system: & \\
\hline & Fixed capital + Running capital & 45720.00 \\
\hline & Depreciation charges: Assuming service life of 10 years straight line depreciation method to calculate & \\
\hline & depreciation charges of equipment. Total depreciation charge per year $=0.10 * 30000$ & 3000.00 \\
\hline & Total running charge including depreciation charges $=10720+3000$ & 13720.00 \\
\hline
\end{tabular}

Table 2. Cost Benefit Analysis 


\section{Conclusion}

It has been found that ion exchange method for copper recovery from acid mine drainage effluents is more economical. Regenerant $\mathrm{NaOH}$ and $\mathrm{HCL}$ with their concentration $10 \%$ and $5 \%$ respectively has found to be most suited. $100 \%$ copper removal was possible at $100 \mathrm{mg} / \mathrm{lit}$. the best suitable $\mathrm{pH}$ is 5 . The capital investment in copper recovery system has been worked out to be as ` 45720.00 The operating cost of copper recovery system will be about`13720.Saving from recovery per annum calculated on the basis of $16.75 \mathrm{Kg}$ cupric chloride recovered per year assuming 300 days of operation will be 9730.00 and standard percentage is 21.28.The process found to be economically feasible.

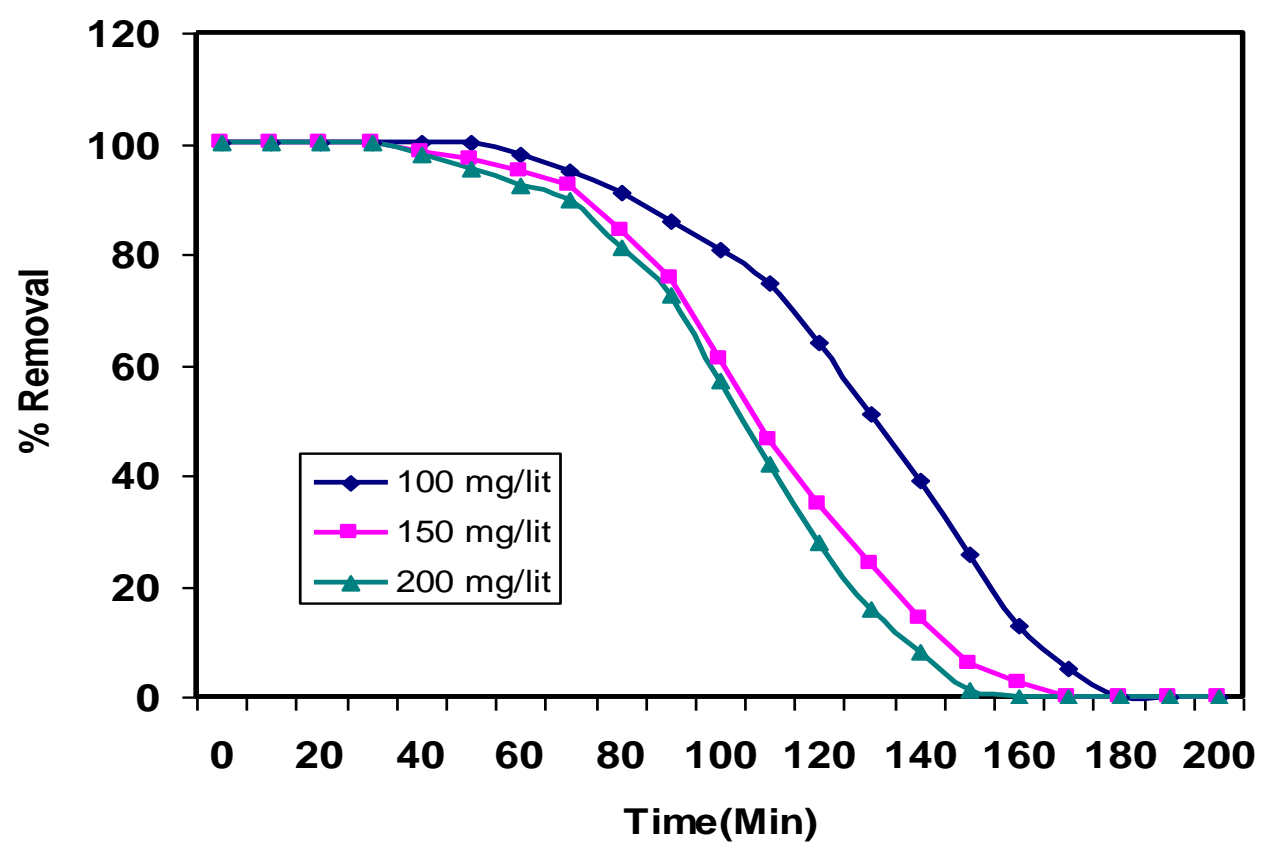

Fig.3 Effect of Concentration on \% Removal

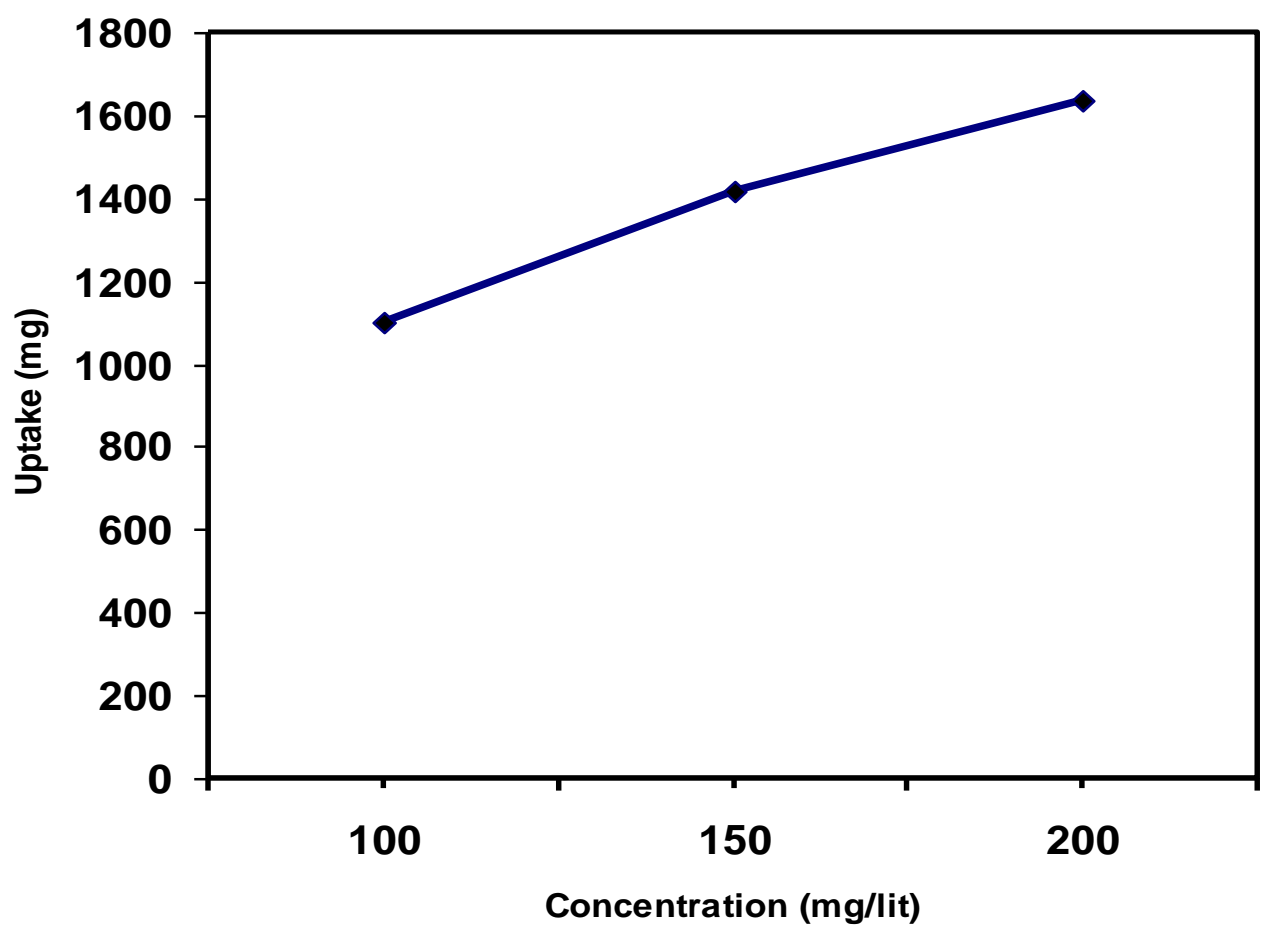

Fig.4 Effect of adsorbate Concentration on Uptake 


\section{References}

1. Kleinman, R.L.P., 1990. Acid mine drainage, US bureau of mines researches and develops: control methods for both coal and metal mines. Environmental Science and Technology 24 (9), $1278-1285$.

2. Fyson, A., Kalin, M., Adrian, L.W., 1994. Arsenic and nickel removal by wetland sediments. In: Proceedings of the International Land Reclamation and Mine Drainage Conference and Third International Conference on the Abatement of Acidic Drainage, vol. 1. Pittsburgh, PA, April 1994, pp. 109-118.

3. Clarke, L., 1996. Coal mining and water quality. Journal of Mines Metals and Fuels 44, 181-183.

4. Kuyucak, N., 2002. Acid mine drainage prevention and control options. CIM Bulletin 95 (1060), 96-102.

5. Filipek, L.H., Hatton, C., Gusek, J., Tsukamoto, T., 2003. Passive treatment of acid rock drainage (ARD): state of the practice. In: Proceedings of the Tenth International Conference on Tailings and Mine Waste, October, 2003, Colorado, USA, pp. 293-303.

6. Modis, K., Adam, K., Panagopoulos, K., Komtopoulos, A., 1998. Development and Validation of a geostatistical model for prediction of acid mine drainage in underground sulphide mines. J. Trans. Instn. Min. Metall. (Sect A: Min. Industry), A102A107.

7. Gaikwad R.W.and Gupta D.V. 2007, Acid Mine Drainage (AMD) Management, Journal of Industrial Pollution Control 23(20), 285-297.

8. Gaikwad R.W.and Gupta D.V.,2008, Review On Removal Of Heavy Metals From Acid Mine.
Drainage , Applied Ecology And Environmental Research 6(3):79-96

9. Kim, J. S., Chah, S. and Yi, J.,2000. "Preparation of Modified Silica for Heavy Metal Removal," Korean J. Chem. Eng., 17, 118-121.

10. Kim, Y., Lee, B. and Yi, J.,2003. "Preparation of Functionalized Mesoporous Silica Containing Magnetite (MSM) for the Removal of Copper Ions in Aqueous Solutions and its Magnetic Separation," Separ. Sci. Technol., Vol. 38, 2533-2548.

11. Lee, B., Kim, Y., Lee, H. and Yi, J., 2001."Synthesis of Functionalized Porous Silicas via Templating Method as Heavy Metal Ion Adsorbents: The Introduction of Surface Hydrophilicity onto the Surface of Adsorbents," Micropor. Mesopor. Mat., 50(1), 77- 90 .

12. Kim, S. J., Lim, K. H., Joo, K.H., Lee, M. J., Kil, S.G. and Cho, S.Y.,2002. "Removal of Heavy Metal Cyanide Complexes by Ion Exchange," Korean J. Chem. Eng., 19(6), 1078-1084.

13. Rengaraj, S. and Moon, S.H., 2002. "Kinetics of Adsorption of Co(II) Removal from Water and Wastewater by Ion Exchange Resins," Water Res., 36, 1783-1793

14. Rengaraj, S., Joo, C., Kim, Y. and Yi, J., 2003."Kinetics of Removal of Chromium from Water and Electronic Process Wastewater by Ion Exchange Resins: 1200H, 1500H and IRN97H," J. Hazard. Mater., B102, 257-275.

15. N.Sakkayawong,P. Thiravetyan, W.Nakbanpote 2005, Adsorption mechanism of synthetic reactive dye wastewater by chitosan, J. Colloid. Interface Sci. $286,36-42$. 